\title{
Pemberantasan Korupsi dalam Perspektif Penegakan Hukum
}

\author{
Artidjo Alkostar
}

The law is never process and its existence free from vacuum space but it becomes and involves with other factors, for instances social, political, economical and cultural factors. Especially in the context of law enforcement regarding the corruption. Besides, the law enforcement also concerning to jurimetrics or the scientific investigation of legal problem. In term of this, the process of law enforcement needs skill and knowledge. According to the author that the corruption in Indonesia constitutes a systemic destructed in political system mechanism, so it is an extra ordinary crimes, it needs to be deconstructed law system and law enforcement system in Indonesia, and the law enforcement in the cases of political corruption in Indonesia needs an integrated institution of law and law enforcement.

Kata-kata kunci: korupsi, sistem hukum, dan nyali baja

$\mathrm{K}$ esaksian sejarah menunjukkan bahwa penegakan hukum tidak pernah berproses di ruang hampa, tetapi senantiasa bersinggungan dengan faktor-faktor lain. Dengan demikian, proses penegakan hukum tidak pernah steril dari hal-hal yang non hukum. Habitat hukum tidak pernah berada dalam ruang yang "vacuum" sosial, politik, ekonomi, dan budaya. Apalagi penegakan hukum yang menyangkut perkara korupsi, atau perkara-perkara lain yang bermuatan politik serta beberapa kasus hukum yang "bertegangan tinggi" lainnya. Penegakan hukum juga menyangkut hal yang bermuatan jurimetrics atau the scientific investigation of legal problem. Dalam arti pula, proses penegakan hukum selalu menuntut adanya skill dan knowledge yang memadai dari para penegak hukum.

Di samping itu, adanya moral yang baik dan mental yang prima dalam diri para penegak hukum menjadi faktor determinan untuk mencapai tujuan maksimal dari penegakan hukum. Prasyarat tersebut merupakań konsekuensi logis dari penegakan hukum yang tidak pernah lepas dari adanya godaan berupa sogokan uang atau janji-janji yang bernilai ekonomis lainnya; serta adanya tantangan berupa ancaman dari kekuasaan politik dan kekuatan fisik. Untuk itu, hanya penegak hukum yang memiliki integritas moral yang berkualitas tinggi dan "nyali" sekuat baja yang dapat menangkal godaan dan melawan ancaman intervensi dari luar tersebut.

Begitu tidak sederhananya proses penegakan hukum, maka suatu pemerintahan banyak yang jatuh, lengser, dilengserkan atau berakhir dengan tidak baik dan menyisakan rasa gemas di hati rakyat disebabkan oleh kegagalan pemerintahan melakukan penegakan hukum. Termasuk Presiden di Indonesia. Secara yuridis telah juga tersedia fasilitas hukum untuk mengusut pemimpin pemerintahan apabila terbukti melakukan perbuatan pidana. Dalam 
perspektif hukum di Amerika Serikat, proses ini dikenal dengan impeachment. Dalam hal ini Michael J. Gerhardt, melukiskan impeachment is a political process designed to investigate, expose, and remedy political crimes committed by special class of politicians subject to unique political punishments. As such, the impeachment process involves tasks incompatible with judicial decision making, including the formulation of impeachable offenses and the balancing of competing political interests. ${ }^{1}$

Kompleksitas penegakan hukum juga berkorelasi dengan vareabel nafsu, ego, dan mentalitas dari komunitas bangsa dan penegak hukum itu sendiri. Keberhasilan pelaksanaan kekuasaan pemerintahan dalam risalah Islam seperti dicontohkan dalam pelaksanaan kekuasaan Nabi Muhammad SAW. Kholifah Umar bin Khatthab, Umar bin Abd. Aziz, dan lain-lain sejenisnya karena mampu mengelola moral komunitas rakyat dan membina mental pejabat pelaksana kekuasaan dengan baik. Salahsatu aspek terpenting dalam revolusi sosial yang dilakukan Nabi Muhammad SAW adalah transformasi moral dan spiritual melalui tingkah laku dan kepribadian. Prinsip-prinsip persamaan, persaudaraan, keadilan, dan kemerdekaan yang dirumuskan sebagai bagian yang utuh dengan iman, telah membentuk akhlak yang luhur dan melahirkan jiwa yang mulia dalam masyarakat. ${ }^{2}$ Begitu pula beberapa pemerintahan di Negara modern saat ini yang tingkat korupsinya sangat rendah, karena ada transparansi pengelolaan pemerintahan dan control sosial masyarakat sipil yang kuat (madani). Pertanyaannya, kapan Negara kita Indonesia dapat dientaskan dari lumpur korupsi yang mencoreng wajah bangsa. Sejak pemerintahan Sukarno, apalagi Soeharto, BJ. Habibie, Abdurrahman Wahid, Megawati
Sukarnoputri, korupsi telah dan selalu menjadi penyakit sosial dan membebani kehidupan rakyat. Lantas bagaimana Presiden SBY, telah dan akan merespon permasalahan bangsa yang kronis ini, perlu dilihat dari program, prioritas agenda, dan nyali para penegak hukumnya.

\section{Program Seratus Hari SBY (Susilo Bambang Yodhoyono)}

Program seratus hari merupakan konsekuensi etis politik suatu pemerintahan baru dalam menjawab kebutuhan mendesak dari rakyat dan representasi keseriusan pemerintah SBY dalam mewujudkan hal-hal yang telah dikampanyekan secara terbuka kepada rakyat Indonesia. Momentum seratus hari dapat dijadikan indikator untuk menakar komitmen, keseriusan, empati, dan kemampuan suatu pemerintahan baru dalam memenuhi janji-janji politiknya, terutama dalam hal ini dalam pemberantasan korupsi.

Korupsi di Indonesia sudah berada dalam stadium kritis, karena termasuk dalam golongan Negara terkorup di Dunia setara dengan Bangladesh, Negeria, dan lain sejenisnya. Korupsi di Indonesia sudah merupakan bagian dari mesin politik, sehingga banyak elit politik nasional dan lokal terlibat dalam kasus korupsi. Apalagi pada era orde baru yang penguasa dan kronikroninya masih ditunggu oleh rakyat untuk diadili agar tidak meninggalkan sisi gelap bagi generasi mendatang. Rakyat Indonesia menunggu sikap ksatria para pemimpin

1 Gerhardt, Michael J. The Federal Impeachment Process, A Constitutional and Historical Analysis, Princeton University Press, Princeton, New Jersey, 1996, Introduction P. xi.

${ }^{2}$ Azzam, Abd-Al-Rahman, Keabadian Risalah Muhammad, PT. Iqra, Bandung, 1983, hal. $62,63$. 
yang korup dan melanggar HAM (hak asasi manusia) seperti yang ditunjukkan oleh pemimpin pemerintahan Korea Selatan, Presiden Chun Do Hwan dan kroninya. Tidak diadilinya koruptor politik di Indonesia telah menjadi beban ekonomi dan biaya politik yang tinggi bagi bangsa Indonesia.

Prasyarat yang harus dipenuhi dalam pemberantasan korupsi adalah pembenahan sistem hukum (legal system) dan sistem penegakan hukum (law enforcement). Dalam arti pula ideologi hukum harus diarahkan sesuai dengan struktur rohaniah rakyat yaitu hukum harus memihak keadilan rakyat banyak. Tentang ideologi hukum, dengan mengutip David Trbubek dan John Esser, seorang penulis sosio-legal theory, Brian Z. Tamanaha menulis bahwa there are number of "legal ideologies". These include the elite production called legal doctrine and everyday understandings about law. Hence, when we speak of legal ideology, we mean views held in society about the nature and function of law. ${ }^{3}$ Harus dihilangkan kesan dan fakta sosial bahwa hukum melindungi pejabat tinggi dan koruptor kakap. Budaya dengan stereotipe bahwa pejabat tinggi sulit diajukan sanksi hukum dan berada di atas hukum harus dihilangkan. Hal ini harus dilakukan dengan pemberian contoh sikap egaliter dari mantan pejabat tinggi atau pejabat tinggi aktif dengan cara jiwa besar mau diadili di muka pengadilan. Tidak terus menerus memakai jurus "sakit", pura-pura sakit, membiarkan maling uang Negara lari keluar negeri. Harus dihilangkan kebuda-yaan memberikan SP3 (Surat Perintah Penghentian Penyidikan/ Penuntutan) dan pemberian RD (Release and Dischard) bagi para pencoleng uang negara.

Macetnya proses penegakan hukum kasus-kasus korupsi (KKN) kelas kakap yang menyangkut big fish, atau tokoh politik, konglomerat hitam, kroni-kroni penguasa Orde Baru, telah dan akan menjadi beban politik bagi pemerintahan SBY. Tugas politik pemerintahan SBY adalah mengembalikan uang negara yang dicuri oleh koruptor kakap kepada rakyat. Ironisnya rakyat banyak hidup dibawah kemiskinan sementara koruptor dengan tanpa sanksi hukum hidup dengan kerakusan ekonomi dan mencuri ratusan trilyun rupiah serta banyak konglomerat yang membawa lari uang negara ke luar negeri.

Pemerintahan SBY ditantang juga untuk membenahi manajemen administrasi keadilan dan pembangunan penegakan hukum. Salah satu diantaranya adalah penerapan reward and punishment untuk membangun citra penanganan perkara yang profesional, sehingga tidak lagi muncul SP3 dan RD yang tidak nalar secara yuridis. Manajemen penegakan hukum yang baik akan memunculkan potensi-potensi penegak hukum yang profesional, berkualitas dan berspirit kerakyatan. Hal ini akan menjadi pupuk tumbuhnya partisipasi masyarakat dalam penegakan hukum, khususnya dalam pemberantasan korupsi seperti yang diperintahkan dalam pasal 41, 42, dan 43 UU No. 31 Tahun 1999 tentang Pemberantasan Tindak Pidana Korupsi. Kuatnya kontrol dari masyarakat madani, akan berbanding lurus dengan berkurangnya peluang atau kesempatan korupsi yang dilakukan pejabat negara dan konglomerat hitam. Masyarakat pada hakikatnya terdiri dari individu-individu. Seperti diteropong dengan kacamata teori Dr. Miqdad Yaljan yang mengatakan bahwa jika individuindividu yang ada itu rusak, maka pondasi bangunan masyarakatpun akan rusak. Bila kondisinya seperti ini, untuk membangun masyarakat madani (civil society) atau

3 Tamanaha, Brian Z., Realistic SocioLegal Theory, Oxford University Press, New York, 1997, p. 86. 
peradaban kemanusiaan yang baik harus dimulai perbaikan masyarakat dengan memperbaiki individu terlebih dahulu. Ini dilakukan dengan jalan membentuk manusia yang baik, baik pada dirinya maupun pada diri orang lain. ${ }^{4}$

Menahan para koruptor kakap dan para konglomerat yang telah mengkorup uang negara melalui BLBI (Bantuan Likuidasi Bank Indonesia) serta menuntut ancaman maksimal atau dengan ancamañ hukuman mati, akan merupakan bagian dari "shock therapy" bagi pemerintahan SBY, karena hal itu akan menimbulkan suasana yang bersifat prevensi umum. Kenyataannya "shock therapy" yang dikumandangkan tidak muncul, sehingga rakyat harus menelan kekecewaan karena haus akan keadilan dan menanti penerapan hukum bagi big fish tetapi tidak juga ada.

\section{Penutup}

- Korupsi di Indonesia, sudah merupakan korupsi sistemik yang telah merusak dalam mekanisme sistem politik. Korupsi yang demikian merupakan korupsi politik yang bersifat luar biasa jahatnya (extra ordinary crimes),

- Diperlukan adanya perombakan sistem hukum dan sistem penegakan hukum dalam rangka merespon fenomena korupsi yang kronis di Indonesia.

- Penegakan hukum dalam kasus korupsi politik, selalu menuntut integritas lembaga penegakan hukum dan penegakan hukum yang "gila" atau yang memiliki nyali baja.

4 Yaljan, Miqdad, Dr., Kecerdasan Moral, Talenta, Yogyakarta, 1983, hal. 36.

\section{Daftar Pustaka}

Azzam, Abd. Rahman,1983, Keabadian Risalah Muhammad, Bandung: Iqra.

Friedman, Lawrence M.,1985, Total Justice, Boston: Beacon Press.

Gerhardt, Michael J., 1996, The Federal Impeachment Process, A Constifutional and Historical Analysis, Princeton, New Jersey: Princeton University Press.

Ghozali, Imam,2000, Pilar-pilar Rohani, Petunjuk Praktis dalam Menempuh Perjalanan Spiritual, Jakarta:Lentera.

Haekal, Muhammad Husain,2003, Umarbin Khattab, Sebuah Telaah Mendalam tentang Pertumbuhan Islam dan Kedaulatannya Masa itu,Jakarta: Litera Antar Nusa.

Halevy Ellie, The Rule of Democracy (19051914),1961,New York: Barnes and Noble Inc.

Jacob, Herbert, Blankenburg, Erhard, et.al.,1996, Courts, Law and Politics in Comparative Perspective, New Haven and London:Yale University Press.

Joseph, Lawrence B., 1995, Crime, Communities, and Public Policy, Center for Urban Research and Policy Studies, The University of Chicago, Chicago:University of Illinois Press.

Martin, Jaqueline, The English Legal System, Hodder and Stoughton, London, 2001.

Sansom, G.B., 1931,Japan A Short Cultural History, Charles E. Tokyo:Tuttle Compeny. 